\title{
Pengembangan Media Pembelajaran Elektronika Dasar Berbasis Komik dengan Adobe Illustrator CS5
}

\author{
Noer Ekafitri Sam ${ }^{1}$, Nurmayanti ${ }^{2}$, Nurjanna $^{3}$ \\ 1. Program Studi Sistem Informasi, STMIK Hasan Sulur Wonomulyo \\ 2. Program Studi Teknologi Pendidikan, Universitas Muhammadiyah Sidenreng Rappang, \\ 3. Program Studi Pendidikan Teknik Elektronika, Universitas Negeri Makassar \\ *e-mail: ${ }^{1}$ noerekafitrisam.nes@gmail.com , ${ }^{2}$ mayantii57@gmail.com, ${ }^{3}$ nurjanna.ftunm@gmail.com
}

\begin{abstract}
Abstrak
Penelitian ini bertujuan untuk mengetahui: (1) proses pengembangan media pembelajaran berbasis komik dengan media adobe illustrator, (2) menghasilkan media pembelajaran berbasis komik dengan media adobe illustrator yang valid dan efektif. Metode penelitian yang digunakan ialah penelitian pengembangan atau research and development mengacu pada model pengembangan Borg and Gall meliputi: (1) tahap perencanaan yaitu menetapkan standar kompetensi, peneltian pendahuluan sesuai silabus, dan pembuatan desain media; (2) tahap pengembangan produk dilakukan pada saat validasi dan uji coba produk; (3) tahap validasi yaitu validasi ahli materi dengan aspek umum, kejelasan materi, dan substansi materi yang berada pada kategori baik sedangkan validasi ahli media dengan aspek umum, media, dan komunikasi visual berada pada kategori baik; (4) Tahap revisi produk dilakukan pada tahapan validasi dan uji coba produk. Adapun perbaikan atau revisi terdapat pada aspek media yaitu layout latar belakang komik, dan komponen perwarnaan bahan elektronika; (5) Tahap uji coba produk akhir media komik dengan menggunakan instrumen tes berupa pretest dan posttest. Hasil penelitian pada kemampuan kognitif terjadinya perubahan positif terhadap hasil belajar berdasarkan nilai pretest dan posttest. Sedangkan hasil instrumen respon siswa menunjukkan bahwa media pembelajaran elektronika dasar berbasis komik dengan aspek umum, media, dan komunikasi visual berada pada kategori sangat baik. Media Pembelajaran Elektronika Dasar Berbasis Komik dengan Adobe Illustrator CS5 yang dikembangkan memenuhi kriteria valid, dan efektif. Untuk itu disarankan media pembelajaran berbasis komik menggunakan adobe illustrator dapat dijadikan sebagai referensi media pembelajaran di kelas yang menyenangkan, mempermudah dalam proses belajar mengajar, dan meningkatkan motivasi dan keingintahuan siswa sehingga hasil belajar yang diperoleh dapat optimal.
\end{abstract}

Kata Kunci: Adobe Illustrator, Media Pembelajaran

\begin{abstract}
Abstrack
This study aims to determine: (1) the process of developing comic-based learning media with adobe illustrator media, (2) producing valid and effective comic-based learning media with adobe illustrator media. The research method used is research and development based on Borg and Gall's development model including: (1) the planning stage, namely setting competency standards, preliminary research according to the syllabus, and making media designs; (2) the product development stage is carried out during product validation and testing; (3) the validation stage, namely the validation of material experts with general aspects, clarity of material, and material substance which are in good categories, while validation of media experts with general aspects, media and visual communication are in good categories; (4) The product revision stage is carried out at the product validation and testing stage. There are improvements or revisions in the media aspect, namely the layout of the comic background, and the coloring component of electronic materials; (5) The final product trial stage of comic media using test instruments in the form of a pretest and posttest. The results of research on cognitive abilities occur positive changes to learning outcomes based on the pretest and posttest scores. Meanwhile, the results of the student response instrument showed that basic electronics learning media based on comics with general aspects, media, and visual communication were in the very good category. Comic-based Basic Electronics Learning Media with Adobe Illustrator CS5 which was developed meets the criteria of validity, and is effective. For this reason, it is suggested that comic-based learning media using adobe illustrator can be used as a reference for learning media in a fun classroom, simplifying the teaching and learning process, and increasing student motivation and curiosity so that the learning outcomes obtained can be optimal.
\end{abstract}

Keywords: Adobe Illustrator, instructional Media 


\section{PENDAHULUAN}

COVID-19 yang mempengaruhi beberapa lini kehidupan termasuk juga dalam bidang Pendidikan. Perubahan kondisi yang terjadi secara mendadak menyebabkan kewalahan tenaga pengajar dalam mempelajari media dan bahan ajar yang harus digunakan dalam pembelajaran online. Sedangkan di sisi lain tenaga pengajar memiliki kewajiban untuk mengupgrade kemampuan dalam mengolah kelas. Hal ini mengacu pada PP Nomor 19 Tahun 2005 Tentang Standar Nasional Pendidikan. Dampak Covid-19 dalam dunia Pendidikan ditandai dengan bermunculannya platform open source online yang digunakan sebagai media pembelajaran seperti e-learning dan video virtual yang mengakibatkan tenaga pengajar hanya fokus pada media yang ingin digunakan bukan bahan ajar yang digunakan dalam proses belajar mengajar.

Modul ataupun buku yang di uploud pada media $e$-learning kurang memberikan motivasi pada peserta didik, hal ini sejalan dengan Penelitian yang dilakukan oleh Novitasari, dkk (2015) yang bertujuan untuk melihat pengaruh media pembelajaran menggunakan komik yang diimplementasikan di SMA dan menghasilkan bahwa komik bisa meningkatkan motivasi peserta didik dalam pembelajaran. Pada tingkat sekolah menengah kejuruan, terbagi atas beberapa kategori jurusan, salah satunya Teknik Elektronika Industri, dimana pembelajaran dasar yang diajarkan yaitu elektronika dasar. Elektronika dasar adalah ilmu elektronika yang mempelajari dasar - dasar komponen, rangkaian, tegangan, karakteristik yang harus terlebih dahulu dipahami dalam membangun sebuah peralatan elektronika. Namun, beberapa fakta yang terjadi di lapangan, salah satunya adalah siswa kurang cepat memahami prinsip-prinsip dasar cara kerja komponenkomponen elektronika. Meskipun, tidak menutup kemungkinan bahwa banyak buku-buku pembelajaran mengenai komponen elektronika yang dapat mereka baca, namun masih banyak pula yang kurang paham.

Situmorang (2009) menyatakan bahwa komik terdiri atas gambar yang bercerita, sehingga komik bisa disajikan tanpa deretan kalimat yang panjang. Namun, penyajiannya tergantung pula pada bagaimana illustrator ingin menyampaikan cerita kepada pembacanya. Komik yang biasa kita jumpai bertemakan super hero, cinta, aksi dan lain-lainya yang memiliki daya tarik penggambaran yang indah serta makna cerita yang energik serta bersifat kepahlawanan, seperti contoh komik Doraemon dan Kyo Samurai Deeper X. Penulis membuat komik yang memiliki tujuan untuk memberi pembelajaran lewat isi materi yang diangkat dalam komik dan memicu motivasi peserta didik dengan melihat illustrasi gambar komponen elektronika. Dengan menonjolkan pengambaran komponen-komponen elektronika yang bercerita serta pelaku karakter yang bercerita tentang keelektronikaan dasar, maka penulis mengharapkan agar pembaca dari komik elektronika ini paham akan dasar elektronika.

Penelitian sebelumnya dilakukan oleh Purnamasari, dkk (2018) berjudul Pengembangan Media Pembelajaran E-Komik pada Materi Dinamika Rotasi yang bertujuan untuk mengembangkan media pembelajaran komik menggunakan model pengembangan ADDIE yang meliputi lima tahapan yaitu analisis, tahap perencanaan, tahap pengembangan, tahap implementasi, dan tahap evaluasi. Hasil validasi media, materi dan uji coba menunjukkan bahwa kategori berada pada range sangat baik, Dan juga dapat meningkatkan motivasi peserta didik dalam pembelajaran. Penelitian lain yang mengangkat media komik dalam penelitian yaitu dari Yuselita (2019) dengan judul Pengembangan Komik sebagai Media Pembelajaran pada Materi Ikatan Kimia (Siswa Kelas X SMAN 1 Benai) menggunakan Penelitian Pengembangan dengan 
model 4D dengan tahapan: pendefinisian, perancangan, pengembangan, dan penyebaran yang menghasilkan media yang valid dan praktis.

Sejalan dengan penelitian yang dilakukan oleh Zainal (2017) berjudul Pengembangan Media Pembelajaran Komik Materi Persamaan Dasar Akuntansi pada siswa kelas XI di SMAN 1 Sambas yang bertujuan mengembangkan media komik menggunakan model Borg and Gall yang memiliki 5 tahapan penelitian yaitu tahap perencanaan, tahap pengembangan produk, tahap validasi, tahap revisi produk, dan tahap uji coba yang menghasihkan keefektifan dan kepraktisan media komik masuk dalam range sangat baik. Hal tersebut juga yang dilakukan pada penelitian ini dengan menggunakan model penelitian yang sama yaitu Borg and Gall tetapi berbeda kondisi dan situasi karena adanya dampak Covid-19. Dimana platform online juga mengambil peran dalam pembelajaran dan dipadu dengan bahan ajar yang menggunakan komik. Mata Pelajaran Elektronika Dasar sangat mendukung untuk media komik karena banyak gambar atau illustrasi bahan elektronika yang dapat dituangkan dalam alur cerita pada komik.

Berdasarkan hal tersebut, maka peneliti melakukan penelitian dengan menggunakan media komik pada mata pelajaran elektronika dasar untuk dikembangkan dan diukur kevalidannya berdasarkan ahli media dan ahli materi.

\section{Metode}

Jenis penelitian yang digunakan yaitu penelitian R \& D (Research \& Development) dengan model penelitan Borg and Gall dengan lima tahapan yang disesuaikan dengan kebutuhan penelitian. Adapun kelima tahapan tersebut adalah tahap perencanaan, tahap pengembangan produk, tahap validasi, tahap evaluasi, dan tahap uji coba akhir. Produk yang dikembangkan berupa buku komik pembelajaran elektronika. Pada tahapan uji coba akhir akan dilakukan metode eksperimen (before-after), dengan cara membandingkan sebelum dan sesudah pemakaian media pembelajaran dengan menggunakan komik. Peneliti hanya menggunakan satu sampel kelas, dengan menggunakan instrumen test berupa pretest dan posttest. Subjek penelitian yaitu siswa kelas X jurusan Teknik Audio Video SMKN 2 Makassar. Treatment akan dilakukan di antara kedua tes tersebut, yaitu penulis mengajar dengan menggunakan media pembelajaran komik setelah melakukan pretest dan kembali melakukan tes setelah treatment dilakukan.

\section{Hasil}

Berikut hasil penelitian pengembangan media pembelajaran elektronika dasar berbasis komik:

A. Prosedur Pengembangan Media Pembelajaran Elektronika Dasar Berbasis Komik

1. Tahap Perencanaan

a. Menetapkan standar kompetensi untuk media pembelajaran yang akan dibuat, penulis terlebih dahulu menetapkan subjek pengguna media pembelajaran, dalam hal ini penulis memilih Kelas X Jurusan Teknik Elektronika Audio Video. Kemudian, standar kompetensi yang penulis tetapkan adalah Elektronika Dasar.

b. Penelitian Pendahuluan Sesuai Silabus

Penelitian pendahuluan sesuai silabus terbagi atas penetapan standar kompetensi, tujuan pembelajaran, dan penetapan topik materi. Pada poin sebelumnya telah dipaparkan standar kompetensi yang ditentukan yaitu: (a) tujuan pembelajaran peserta didik memiliki pengetahuan, keterampilan dan sikap dalam memahami komponen-komponen elektronika, (b) penetapan topik materi yaitu komponen dasar elektronika. 
c. Pembuatan Desain Media

Desain media menggunakan software Adobe Illustrator CS5. Untuk mendesain komik, secara teknis penulis membagi tiga bagian kerja yang harus dilakukan. Bagian kerja pertama, menentukkan topic komik dan pembuatan karakter komik. Bagian kerja kedua, membuat latar belakang komik dan gambar pendukung lainnya. Dan bagian kerja ketiga adalah penyusunan komik menjadi buku untuk dicetak.

Berikut desain komik menggunakan aplikasi adobe illustrator CS5:

(1) Penetapan topik komik dan pembuatan karakter komik

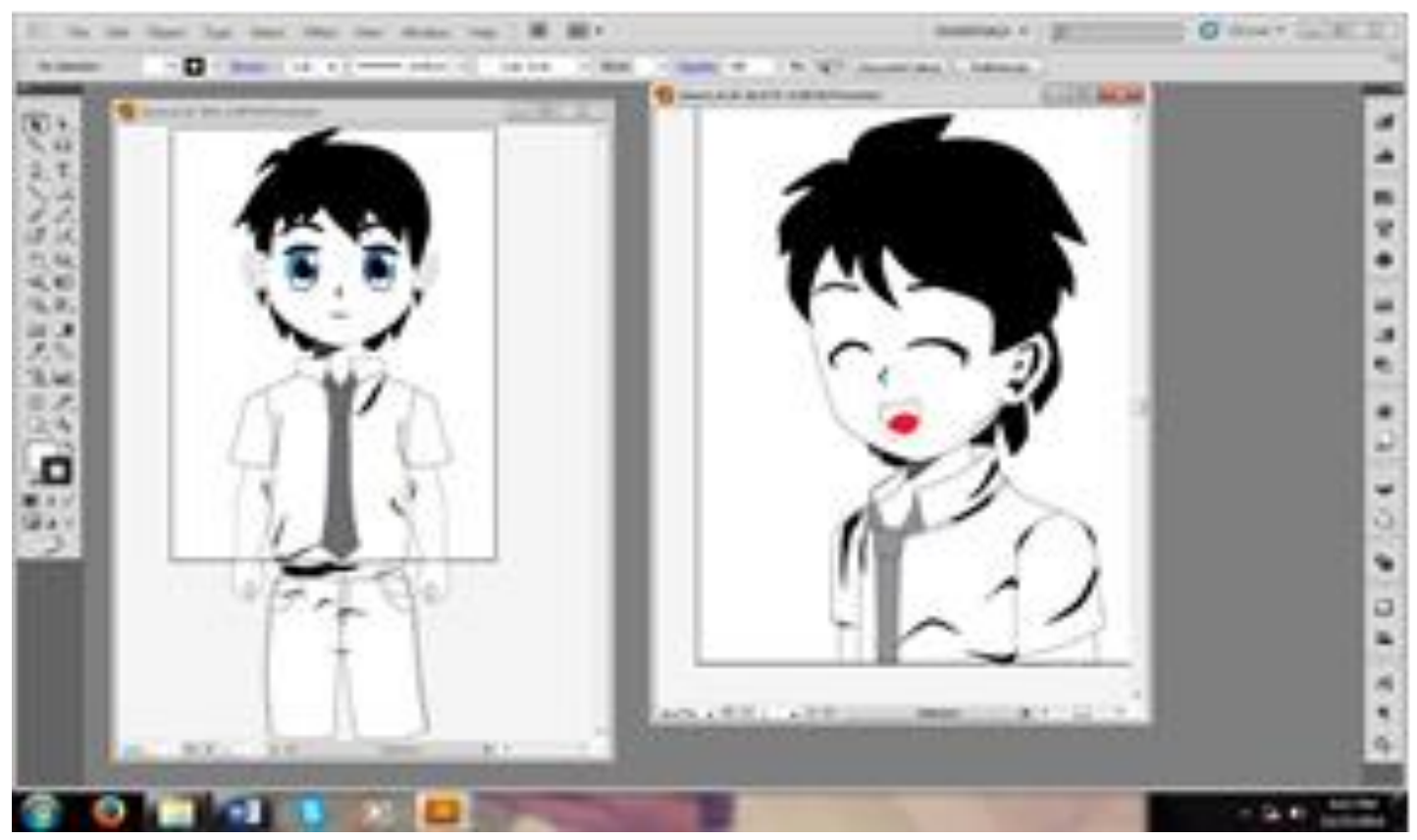

Gambar 1. Pembuatan Karakter Komik

(2) Pembuatan latar belakang (background komik) dan gambar pendukung lainnya

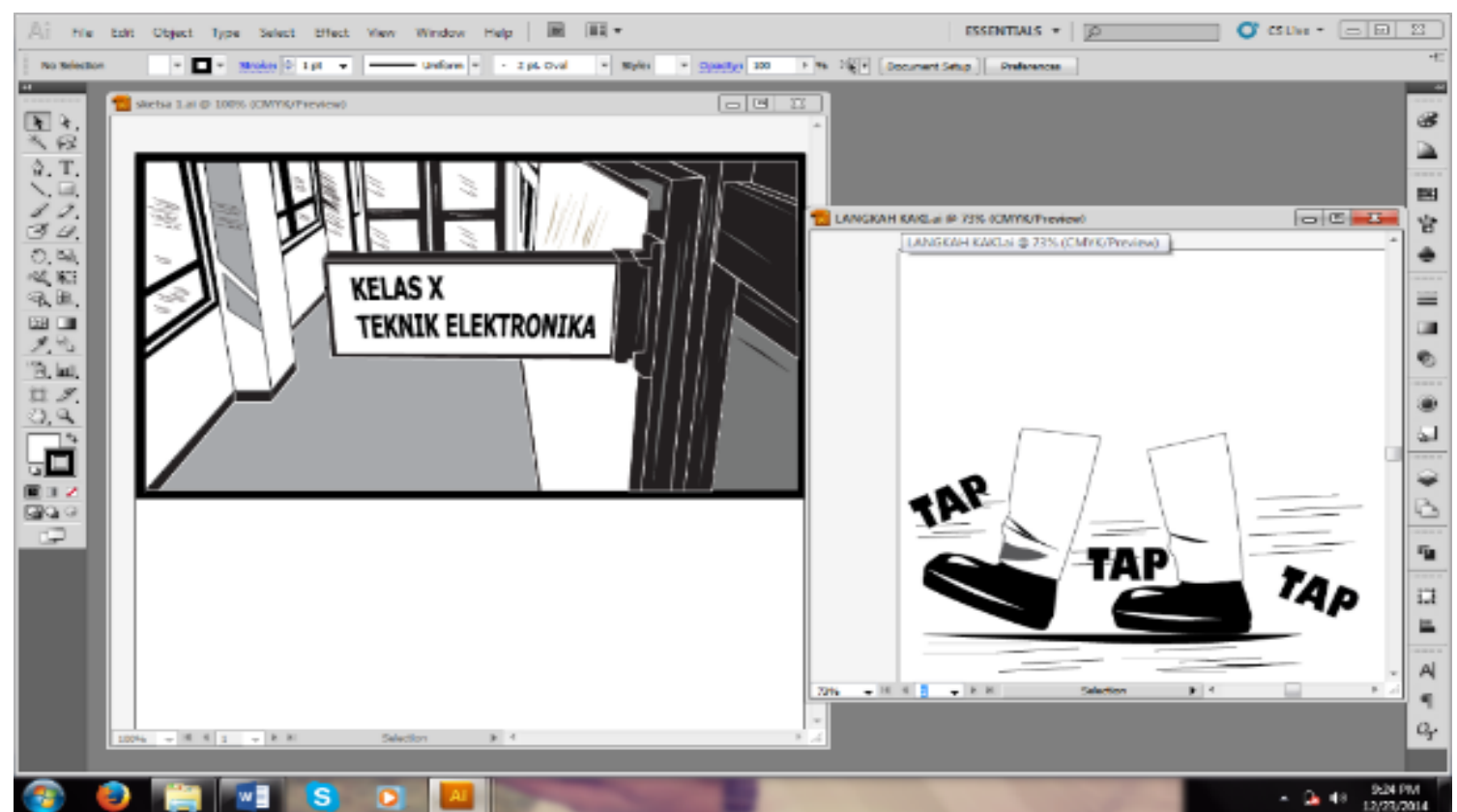

Gambar 2. Pembuatam latar belakang komik dan gambar pendukung 
(3) Pembuatan Alur Cerita (Penggabungan)

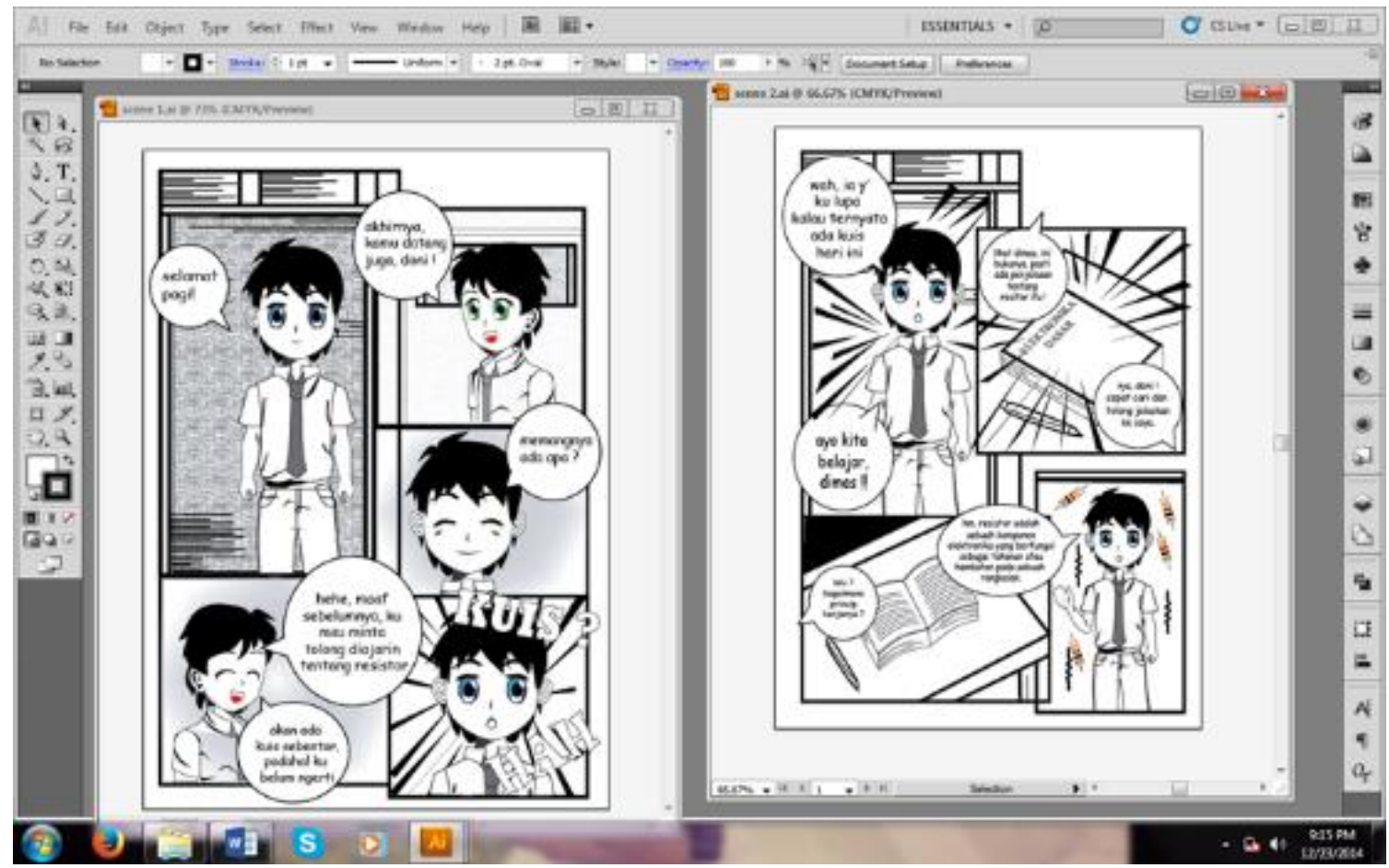

Gambar (a)

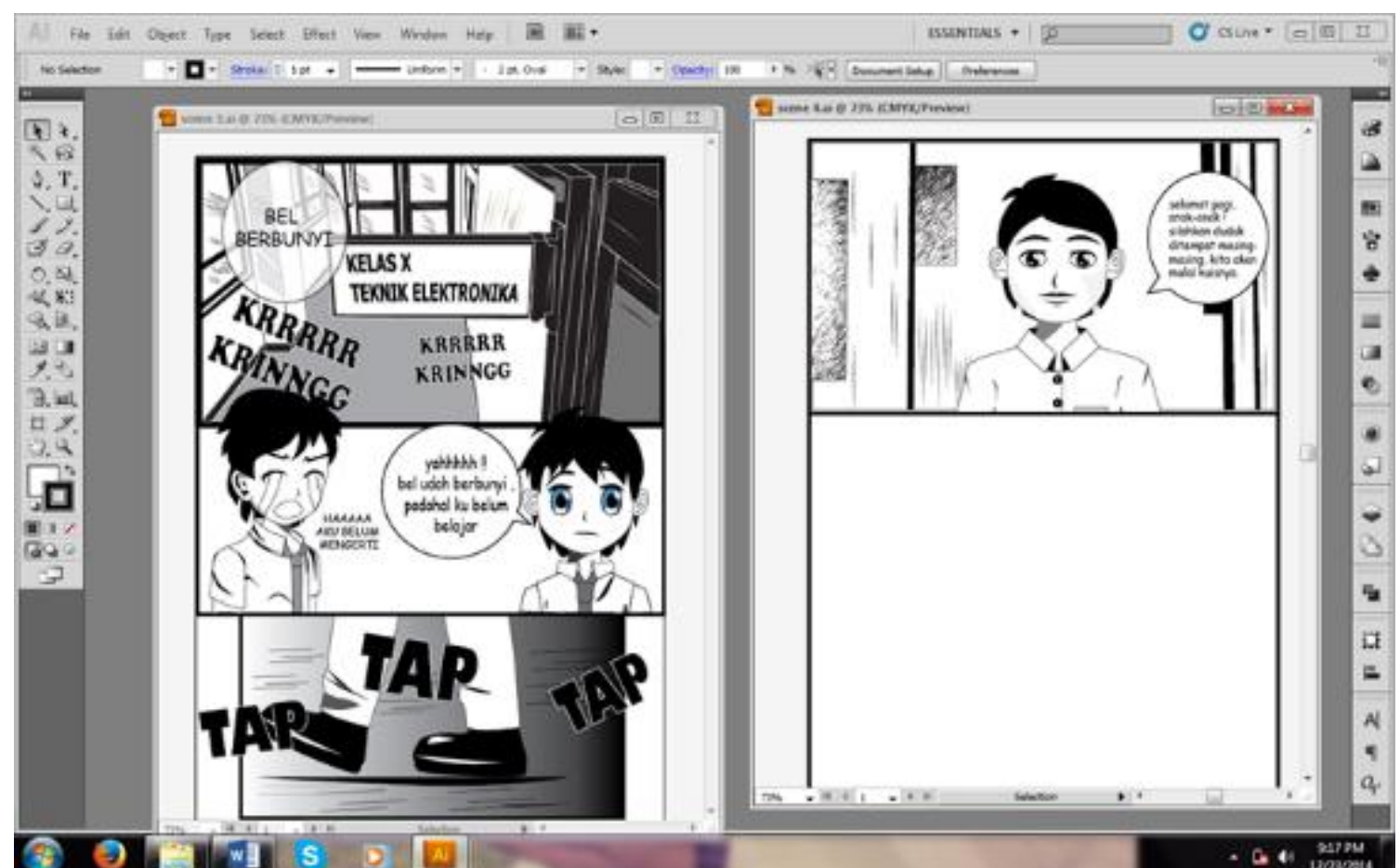

Gambar (b).

Gambar 3. (a) dan (b). Pembuatan alur cerita (penggabungan) 
2. Pengembangan Produk

Melakukan pengembangan dengan Validasi kemudian melakukan evaluasi dari hasil validasi. Evaluasi pertama adanya permintaan perbaikan layout latar belakang komik dan komponen perwarnaan komponen elektronika. Revisi kemudian melakukan validasi akhir.

3. Tahap Validasi

a. Validasi Ahli Materi.

Validasi Ahli materi yang dilakukan expert judgement yang merupakan salah satu Dosen Universitas Negeri Makassar Fakultas Teknik Program Studi Pendidikan Teknik ELektronika. Adapun aspek yang dinilai yaitu: aspek umum meliputi kandungan materi, presentasi informasi, estetika secara keseluruhan, fungsi yang diharapkan (menunjang pembelajaran), dan kualitas secara umum. Adapun hasilnya dapat di lihat pada Tabel 1 sebagai berikut.

\section{Tabel 1. Hasil Validasi Ahli Materi}

\begin{tabular}{clc}
\hline No. & \multicolumn{1}{c}{ Indikator } & Persentase \\
\hline 1 & Umum & $96 \%$ \\
2 & Kejelasan & $92.7 \%$ \\
3 & Substansi Materi & $90 \%$ \\
\hline \multicolumn{2}{r}{ Rata-rata } & $94.84 \%$ \\
\hline
\end{tabular}

Dari tabel hasil validasi ahli materi terlihat hasil fudgement dari ahli materi, mulai dari aspek umum hingga substansi materi dengan rata-rata $94.84 \%$ atau dikategorikan sangat baik. Sehingga ahli materi menyatakan bahwa produk pembelajaran ini dinyatakan layak diujicobakan di lapangan

b. Validasi Ahli Media

Validasi ahli media yang dilakukan expert judgement yang merupakan salah satu Dosen Universitas Negeri Makassar Fakultas Teknik Program Studi Pendidikan Teknik ELektronika. Adapun yang dinilai meliputi, efektif dan efisien dalam penggunaan media pembelajaran, kehandalan program (tingkat error/tolerance), maintainable (kemudahan pemeliharaan/pengelolaan), Usebilitas (kemudahan penggunaan/pengoperasian), ketepatan pemilihan jenis aplikasi/software/tool untuk pengembangan, kompabilitas, pemaketan program media pembelajaran terpadu dan mudah dalam eksekusi, dokumentasi program media pembelajaran lengkap, reusable. Adapun hasilnya dapat di lihat pada Tabel 2 sebagai berikut.

Tabel 2. Hasil Validasi Ahli Media

\begin{tabular}{clc}
\hline No. & \multicolumn{1}{c}{ Indikator } & Persentase \\
\hline 1 & Umum & $84 \%$ \\
2 & Media & $91.1 \%$ \\
3 & Komunikasi Visual & $90.9 \%$ \\
\hline \multicolumn{2}{r}{ Rata-rata } & $84.4 \%$ \\
\hline
\end{tabular}

Dari tabel hasil validasi expert judgement media terlihat hasil fudgement dari ahli media, mulai dari aspek umum hingga komunikasi visual dengan rata-rata $84.6 \%$ atau 
dikategorikan baik. Sedangkan expert judgement materi menyatakan bahwa produk pembelajaran ini dinyatakan layak diujicobakan dilapangan

4. Tahap Revisi Produk

Tahap revisi produk dilakukan pada tahapan validasi expert yang adanya perbaikan pada aspek media yaitu layout latar belakang komik, dan komponen perwarnaan bahan elektronika. Revisi kemudian melakukan validasi akhir

5. Tahap Uji Coba Produk Akhir

Tahap uji coba produk akhir dilakukan untuk melihat keefektifan pembelajaran menggunakan media komik dengan menggunakan instrument tes berupa pretest dan posttest. Subjek penelitian adalah siswa Kelas X Jurusan Teknik Elektronika Audio Video menghasilkan adanya peningkatan hasil belajar kognitif siswa pada saat posttest. Selain dari itu instrument angket juga diberikan kepada subjek penelitian untuk menilai dan mengukur media pembelajaran dengan indicator sebagai berikut: aspek umum, kejelasan media, dan komunikasi visual. Adapun hasilnya dapat di lihat pada Tabel 3 sebagai berikut.

\section{Tabel 3. Respon Siswa Kelas X Jurusan Teknik Elektronika Audio Video Terhadap Media Pembelajaran Komik}

\begin{tabular}{clcl}
\hline No. & Indikator & Persentase & Kategori \\
\hline 1 & Umum & $98,3 \%$ & Sangat Baik \\
2 & Media & $96 \%$ & Sangat Baik \\
3 & Komunikasi Visual & $95,8 \%$ & Sangat Baik \\
\hline & Rata-rata & $96.7 \%$ & Sangat Baik \\
\hline
\end{tabular}

\section{Pembahasan}

Penelitian Pengembangan Media Pembelajaran Elektronika Dasar berbasis komik dengan adobe illustrator CS5 menggunakan jenis penelitian pengembangan dengan model Borg and Gall yang disesuaikan dengan kebutuhan penelitian, yang bertujuan untuk menghasilkan media pembelajaran komik yang valid dan efektif. Hasil validasi expert judgement media dan materi setelah melakukan satu kali revisi didapati hasil akhir yang menyatakan media pembelajaran komik valid atau layak digunakan dilapangan.

Implementasi media pembelajaran komik dilakukan pada saat uji coba akhir untuk mengukur tingkat keefektifan media dengan subjek siswa kelas X jurusan Teknik Audio Video SMKN 2 Makassar. Adupun aspek yang diukur adalah aspek kognitif dengan melihat perbandingan pretest dan posttest didapati hasil adanya peningkatan pada saat posttest. Faktor pendukung lainnya terlihat pada instrumen angket yang dibagikan kepada siswa untuk mengukur respon siswa terhadap media pembelajaran berbasis komik dengan menilai tiga aspek yaitu aspek umum, aspek media, dan aspek komunikasi visual yang berada pada kategori sangat baik.

Sedangkan penelitian terdahulu yang dilakukan oleh Zainal (2017) berjudul Pengembangan Media Pembelajaran Komik Materi Persamaan Dasar Akuntansi pada siswa kelas XI di SMAN 1 Sambas juga meningkatkan hasil belajar siswa tetapi menggunakan kompetensi dan kondisi yang berbeda dengan penelitian ini. Berdasarkan hal tersebut maka dapat disimpulkan bahwa media 
komik sangat baik digunakan sebagai media pembelajaran dengan kompetensi bidang ilmu tertentu.

\section{Kesimpulan}

Berdasarkan hasil analisis yang telah dijelaskan pada bab sebelumnya, maka kesimpulan yang dapat diambil dari penelitian ini adalah sebagai berikut:

1. Pengembangan media pembelajaran elektronika dasar berbasis komik menggunakan adobe illustrator dilakukan tahap demi tahap sesuai prosedur yang benar.

2. Penilaian expert judgement meliputi ahli media dan ahli materi menyatakan bahwa media pembelajaran elektronika dasar berbasis komik ini sudah sangat baik dan layak untuk di ujicoba. Secara umum ahli materi dan ahli media mengomentari bahwa ini adalah suatu ide yang kreatif dan inovatif.

3. Adapun peserta didik menanggapi bahwa media ini membantu dalam pembelajaran dengan respon yang sangat baik.

\section{Referensi}

Darma, Putra. 2010 Pengolahan Citra Digital, Penerbit Andi, Yogyakarta.

Fifi Novitasari, Yulia Jahir, Siti Fatimah. 2015. Pengaruh Media Adobe Illustrator Terhadap Hasil Belajar Peserta Didik Pada Mata Pelajaran Ekonomi Di SMA Srijaya Negara. 2(1), 60-67.

Henny Purnamasari, Siswoyo, Vina Serevina. Pengembangan Media Pembelajaran E-Komik Pada Materi Dinamika Rotasi” Prosiding Seminar Nasional Fisika, vol 7, no 10.21009/03. SNF 2018.

Peraturan Pemerintah Nomor 19 Tahun 2015 Standar Nasional Pendidikan, 5 Mei 2015. Lembaran Negara Republik Indonesi Tahun 2015. Jakarta.

Purnomo Mauridhi Hery, Muntasa Arif, 2010. “Konsep Pengolahan Citra Digital dan Ekstraksi Fitur". Graha Ilmu, Yogyakarta.

Situmorang, Anggie Maritta Rebecca. 2009. Komik Jepang dan Pengetahuan Mahasiswa (Studi Korelasi Pengaruh Komik Doraemon dan Kyo Samurai Deeper X Terhadap Pengetahuan Mahasiswa FISIP USU tentang kebudayaan Jepang). Fakultas Ilmu Sosial dan Politik. Universitas Sumatera Utara. Medan.

Sutoyo. T, Mulyanto. Edy, Suhartono. Vincent, Dwi Nurhayati Oky, Wijanarto, 2009. "Teori Pengolahan Citra Digital". Andi Yogyakarta dan Udinus Semarang.

Yuselita, Rabiul. 2019. Pengembangan Komik Sebagai Media Pembelajaran pada Materi Ikatan Kimia (Siswa Kelas X SMAN 1 Benai). Vol 1, No 1. 103-109.

Zainal. 2017. Pengembangan Media Pembelajaran Komik Materi Persamaan Dasar Akuntansi pada Siswa Kelas XI di SMA Negeri 1 Sambas. Vol 6, No. 10. 